\title{
THE INFLUENCE OF PRODUCT MIX ON SALES GROWTH OF AYURVEDIC PRODUCTS IN INDIA
}

\author{
Gyanendra Chaturvedi \\ chaturvedi.gyanendra@gmail.com \\ Dr Manas ranjan Dasmishra \\ dashmishra@gmail.com \\ Dr Ajit Upadhyaya \\ ajit_upadhyaya@pimrindore.ac.in
}

\begin{abstract}
Modern world is facing a virtual crisis with human diseases surpassing the immune system of the body and Allopathic system of medicine finding it hard to keep pace with the changes in the contemporary malignant bacteria. The world is now gradually turning towards nature for the cures rather than the chemical therapy, which according to the masses leads to uninvited side effects. The natural therapy assures of almost no side effects, but the recovery is always gradual albeit permanent.

Ayurveda is a form of alternative medicine that finds its history thousands of years ago in the Indian culture. According to Merriam Webster, Ayurveda can be defined as seeking to treat and integrate body, mind and spirit using a comprehensive approach by emphasizing on diet, herbal remedies, exercise, meditation and breathing therapy. India being the origin place of 'Ayurveda' finds its theories in the ancient 'Vedas', thus is more than a thousand years old. Fragrance of Ayurveda has been commercialized by certain Indian companies like Dabur, Patanjali and Himalayan etc. These companies like Patanjali and Himalayan find their origin in 1930s in the form of trust for human services.
\end{abstract}

This research is an empirical study that would analyze major Indian Ayurvedic companies and study the role of Product and Services in case of Ayurveda product sales. The study has been conducted with the primary data collected in the form of a structured questionnaire from various company executives, and statistical tools were applied for the analysis of the data. Multiple linear regression was the major tool applied and the impact of product mix was studied on the sales growth of the Ayurvedic companies. 
The results implied positive effect of certain elements of product mix on the sales growth of the Ayurvedic companies, thus concluding major role of product line, service quality and packaging on the increase in the sales aspect.

Keywords: Product mix, Himalayan, Patanjali.

Cite this Article: Gyanendra Chaturvedi, Dr Manas ranjan Dasmishra, Dr Ajit Upadhyaya, The Influence of Product Mix on Sales Growth of Ayurvedic Products in India, Journal of Management (JOM), 6 (4), 2019, pp. 13-16.

$\mathrm{http}: / / \mathrm{www}$. iaeme.com/JOM/issues.asp?JType=JOM\&VType=6\&IType=4

\section{INTRODUCTION}

Ayurveda is a science which finds its origin thousands of years ago in the Indian 'Vedas', but was not given the deserving accreditation for the same, primarily by the Indian people themselves. This science prevailed throughout India in clusters, somewhere in Kerala, in Maharashtra, in Northern India, but was never accepted as the primary science for curing disease among the masses. The tradition of 'Vaidyas' diagnosing the disease with the 'nadi' analysis did not find all pervasive acceptances but rather in distant interior regions of India.

The history of the modern Ayurveda in India is found since 1930s when Mr M Manal observed Rauwolfia Serpentina being used as a pacifying agent for the restless elephants. Resulting in the origin of Himalayan company which dominated the Indian market through its still popular product named 'Liv.52', a highly effective liver medicine. Patanjali another Indian Ayurvedic product promoting company also finds its origin in the 1930's when Patanjali Yogpeeth trust was formed. Thus the Indian Ayurveda found its presence in the form of Ayurvedic companies, which commercialized the science towards finding its acceptance among the Indian masses.

Marketing of Ayurvedic products involves certain elements of marketing mix being taken care of individually, they include Product Mix, Price, Place (distribution) and Promotion. The product mix includes complete assortment of products that are offered by the company to its consumers (businessjargons.com). Price involve the discounts, the offers, the deductions and the area-wise pricing that was being offered by the company for the various products to the masses. Place includes the distribution of the products segments and area-wise as per the requirement of the company needs and available resources. Finally the promotion of the products is the one that finds an important place in the marketing section of any organization.

In this study the focus is on the product mix offered by the Ayurvedic companies in India, which would include the Product line i.e. the portfolio of products that are being offered by the company. Product quality is another aspect that is being taken care of by the organizations towards maintaining a product mix, product quality involves the features that determine its desirability of the product to meet certain basic requirements (businessdictionary.com). Technological advancement in the product is another dimension that is being analyzed in this study of the product mix. Packaging is another aspect of the product mix that influences the marketing of the product.

\section{OBJECTIVE OF THE STUDY}

The objective of this research is to analyze the influence of Product mix on the growth of sale of the Ayurvedic organization. 


\section{RESEARCH METHODOLOGY}

The objective of the study is to analyze the product mix of the Ayurvedic product and their influence on the sales and for the research purpose certain steps are being followed they are:

Method of Research: This is a descriptive research method, the research being done with help of survey through a structured questionnaire. The primary data is collected through a questionnaire framed for the Ayurvedic company executives.

Sample: The Convenient Sampling technique was being used in the study, the sample size has been 100 in number. Executives of different Ayurvedic companies were being circulated the questionnaire and their responses were noted.

Tools used for data collection: Secondary data regarding the Ayurvedic companies was collected from journals, internet, books and newspapers etc. primary data was collected through a structured questionnaire.

\section{ANALYSIS OF DATA}

This study has been conducted on a sample size of 100 , different executives from various Ayurvedic companies in India, the primary data has been collected through a structured questionnaire. The questions covered the product mix which involved 'increase in Product Line extension', 'increase in technical sophistication', 'product quality', 'service quality along with attractive packaging of product' with respect to their competitors.

To study and analyse the impact of various aspects of product mix like the product line, the technical sophistication, the product quality, service quality have been studied on the increase in the sales as compared to the past year. With the help of SPSS 25.0, Multiple linear regression was applied to study the impact of product mix on sales growth.

The regression analysis displayed the following aspects:

Table 1 Model Summary

\begin{tabular}{|c|c|c|c|c|}
\hline $\mathbf{R}$ & R SQUARE & $\begin{array}{c}\text { ADJUSTED R } \\
\text { SQUARE }\end{array}$ & $\begin{array}{c}\text { STD ERROR OF THE } \\
\text { ESTIMATE }\end{array}$ & $\begin{array}{c}\text { DURBIN- } \\
\text { WATSON }\end{array}$ \\
\hline .648 & .420 & .390 & .96839 & 1.853 \\
\hline
\end{tabular}

The model summary displays that the product mix does have $39 \%$ impact on the sales growth of the Ayurvedic products which is commendable. The Durbin-Watson value also displays that there is no auto-correlation within the data.

The ANOVA table is being displayed as following

Table 2 Anova

\begin{tabular}{|l|c|c|c|c|c|}
\hline & $\begin{array}{c}\text { SUM OF } \\
\text { SQUARES }\end{array}$ & Df & $\begin{array}{c}\text { MEAN } \\
\text { SQUARE }\end{array}$ & F & Sig \\
\hline REGRESSION & 65.268 & 5 & 13.054 & 13.920 & .000 \\
\hline RESIDUAL & 90.026 & 96 & .938 & & \\
\hline TOTAL & 155.294 & 101 & & & \\
\hline
\end{tabular}

The ANOVA table displays that the model is significant

Certain significant values are being displayed in the coefficient table

\section{Hypothesis testing}

There is significant impact of increase in the Product Line of Ayurvedic products on the sales growth of the organization $(\mathrm{p}=.008)$ 
There is no significant impact of technology of the product, Product quality, Service quality and attractive packaging of the Ayurvedic product on the Sales growth of the organisation.

Table 3 Coefficient

\begin{tabular}{|l|c|c|c|c|c|}
\hline \multirow{2}{*}{} & \multicolumn{2}{|c|}{$\begin{array}{c}\text { UNSTANDARDIZED } \\
\text { COEFFICIENTS }\end{array}$} & $\begin{array}{c}\text { STANDARDIZED } \\
\text { COEFFICIENTS } \\
\text { BETA }\end{array}$ & t & sig \\
\cline { 2 - 3 } & $\mathrm{B}$ & Std Error & & & \\
\hline Increase in product line & .400 & .148 & .400 & 2.708 & .008 \\
\hline Increase in Service Quality & .197 & .209 & .217 & .944 & .347 \\
\hline Attractive packaging & .132 & .099 & .137 & 1.333 & .186 \\
\hline
\end{tabular}

\section{DISCUSSION AND CONCLUSION}

This study revealed that the Product mix which comprised of Product quality, Service quality packaging and technological advances did not have a significant impact on the sales growth of the organization. Thus any company if enhances the product line of its Ayurvedic products then it would be adding to the sales growth. A major impact of increase in the Product line can be favorable for the sales growth compared to other aspects of product mix, it is found that .400 is the value of unstandardized coefficient, which is highest among all five aspects of the product-mix.

The conclusion from the above study can be stated that if a variety of Ayurvedic products are being launched by any company then it will be accepted by the consumers accordingly. Patanjali is the live example in the Indian Ayurvedic market; we can observe miscellaneous products in the Patanjali stores from biscuits to medicines. The analysis from this study can conclude that product quality and technology are having hardly any impact on the sales, besides a nominal contribution of service quality and packaging does make a difference.

\section{REFERENCES}

[1] Aarogya Angk extended edition. (2015). Gorakhpur: Gita Press .

[2] (2018). Retrieved from http://www.tkdl.res.in/tkdl/langdefault/ayurveda/Ayu_Principles.asp?GL=\#q5.

[3] (2018). Retrieved from https://www.ayurtimes.com/sapta-dhatu-in-ayurveda/.

[4] (2018). Retrieved from https://www.statisticssolutions.com/factor-analysis-sem-factoranalysis/.

[5] (2019). Retrieved from http://www.ayush.gov.in/about-the-systems/ayurveda.

[6] Wikipedia.org. (n.d.). 